\title{
LOCATION CHOICE OF SPANISH MULTINATIONAL FIRMS IN DEVELOPING AND TRANSITION ECONOMIES
}

\author{
Josep MARTÍ 1 , Maite ALGUACIL ${ }^{2}$, Vicente ORTS $^{3}$ \\ ${ }^{1}$ Department of Economics, Universitat Jaume I, Av de Vicent Sos Baynat, \\ 12071 Castelló de la Plana, Spain \\ ${ }^{2,3}$ Department of Economics and Institute of International Economics, \\ Universitat Jaume I, Av de Vicent Sos Baynat, 12071 Castelló de la Plana, Spain \\ E-mails: '1arnauj@uji.es; ${ }^{2}$ alguacil@uji.es (corresponding author); ${ }^{3}$ orts@uji.es \\ Received 12 February 2014; accepted 28 January 2015
}

\begin{abstract}
In this paper, we use firm-level data to investigate how different host country characteristics affect the decision of Spanish multinational firms to locate in developing and transition countries, and whether these determinants change when looking at manufacturing or services firms. As a methodological novelty, we estimate both standard conditional logit models as well as other discrete choice models that allow us to account for the possibility that firms perceive some alternative destinations as being more similar (nested and mixed logit models). A better understanding of the relevance of local factors that determine the competitiveness of these economies in providing multinational firms with location advantages can guide policymakers in their attempt to attract foreign capital flows. This, however, has not been previously addressed by the empirical literature at a firm level and across sectors. Our results suggest that Spanish investments in developing and transition economies are mainly driven by market-seeking factors. They also confirm the relevance of the business and financial climate in the location decision of multinational firms. Finally, the estimations reveal differences between manufacturing and services foreign direct investments in several local factors, such as the agglomeration effects, skilled labour and financial risk.
\end{abstract}

Keywords: Spain, location choice, nested and mixed logit models, developing and transition countries, multinational firms, manufacturing and services foreign direct investments.

JEL Classification: F21, F23, R39.

\section{Introduction}

Multinational enterprises (MNEs) and transnational investments have played a prominent role in the process of globalisation. Linked to this activity of MNEs, worldwide foreign direct investment (FDI) has risen considerably, changing the landscape of the global economy ${ }^{1}$. For decades, FDI flows from high-income developed countries to

\footnotetext{
${ }^{1}$ Specifically, annual FDI increased six-fold from US\$ 241 million in 1990 to US\$ 1.451 million in 2010. In 2011, despite the global economic crisis, FDI inflows still rose by $16 \%$ (UNCTAD 2012). After a decline in 2012, global foreign direct investment flows rose again by 9 per cent in 2013, and it is expected to continue growing in the years to come (UNCTAD 2014).
} 
other high-income countries have been an empirical regularity of cross-country investments. However, this tendency has recently been inverted, increasing the relevance of developing and transition countries as recipients of these flows. Indeed, in 2010, for the first time, developing and transition economies attracted more than 50\% of global FDI inflows (UNCTAD 2012) $)^{2}$. At the same time, such as can be appreciated in Figure 1, there has been a significant change in the sectoral composition of these flows, with a sharp increase in FDI in services at the expense of the manufacturing industry. Additionally, as shown in the same Figure, this growth in the share of services FDI has been higher for developing than for developed countries since last decade of the past century.

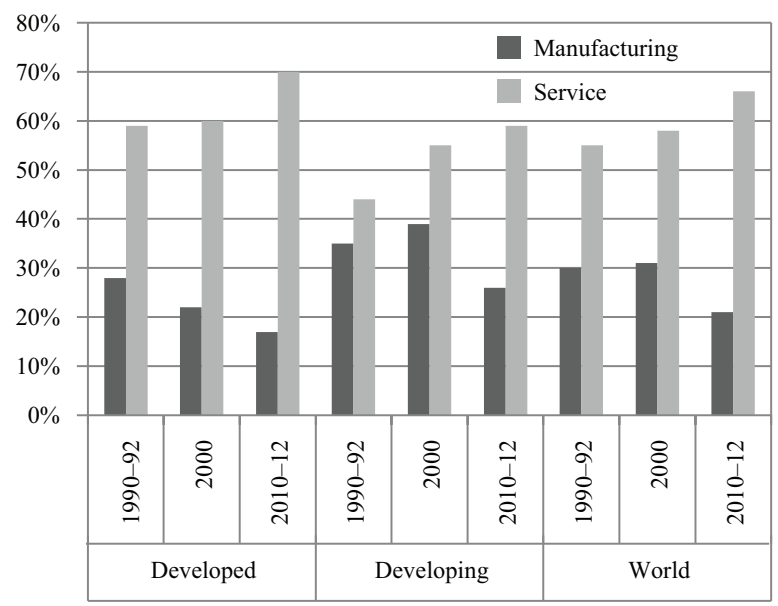

Fig. 1. Trends in the sectoral composition of FDI inflows: share of each sector in total FDI inflows, 1990-2012

Source: Own elaboration based on World Investment Report (see UNCTAD 2014).

In spite of this recent behaviour of FDI, the location choice of service firms' foreign affiliates in developing countries has not received a great deal of attention from researchers. Most empirical studies that analyse the location decision of MNEs have focused mainly on developed economies and on manufacturing sectors ${ }^{3}$. As an exception, we can mention the work by Blonigen and Wang (2005), which offers empirical evidence of the different behaviour of FDI in developed and developing countries ${ }^{4}$. Similarly, Spies (2010) shows that the patterns of foreign production location decisions might differ significantly between manufacturing and services.

\footnotetext{
${ }^{2}$ In 2013, these economies attracted more than 60 per cent of global FDI inflows.

${ }^{3}$ As is the case of Crozet et al. (2004) for France; Head and Mayer (2004) for Japanese MNEs in Europe and Basile et al. (2008) for MNEs in Europe.

${ }^{4}$ Apart from China (and other Asian-Pacific countries), the literature had also marginalised the studies about MNEs' location choice in transition economies. The few studies that do analyse the location pattern of FDI in transition economies have been limited to empirical studies at a regional level (see, for instance, Pusterla, Resmini 2007).
} 
In this paper, we use firm-level data to investigate how different host country characteristics affect the decision of Spanish MNEs to locate in a large sample of developing and transition countries ${ }^{5}$, and whether these determinants change when looking at manufacturing or services firms. The recent behaviour of Spanish FDI flows makes the case of this country particularly relevant for the study of the location determinants of foreign affiliates in developing and transition countries by sectors. Since the mid-90s, Spain has become a big player in the world's outward FDI, changing from being a net recipient of foreign investment to a net investor. Moreover, a large amount of these investments have been directed towards less developed economies. To the best of our knowledge, no studies have been conducted about the determinants of location choices of foreign affiliates across sectors with a large sample of developing and transition economies at firm level. The few studies that do analyse the divergences in the location criteria between FDI in services and manufacturing activities concentrate on developed economies $^{6}$. Furthermore, we provide a methodological contribution by estimating both standard conditional logit models as well as other discrete choice methods that allow us to account for the possibility that firms perceive some alternatives as being more similar to one another than others, like the nested and the mixed logit models. Indeed, this latter methodology has barely been used in the recent empirical literature despite its advantages in considering more complex substitution patterns among the choices, thus avoiding the restrictive assumptions of the previous methods.

Following recent literature, in the empirical analysis special attention is paid to the relevance of agglomeration effects, and the size and quality of host and surrounding markets in attracting FDI flows, jointly with other local factors, such as the endowment of infrastructures, the skills and cost of workforce or the distance between home and host countries (Disdier, Mayer 2004; Pusterla, Resmini 2007; Basile et al. 2008; Spies 2010). As a novelty in the study of the location decision of FDI in developing countries, the role played by macroeconomic instability and the institutional and financial frameworks is also contemplated.

The main findings of this study are as follows. Firstly, it is shown that both market size and agglomeration economies constitute important determinants for the location choice of Spanish MNEs in developing and transition economies. In line with our predictions, the positive externalities of agglomerations of foreign firms seem to dominate in the attraction of FDI. However, the behaviour of these positive spillovers is observed to differ depending on both the sector activity and the nationality of the competitors. Secondly, according to our estimates, the influence of human capital and macroeconomic climate on the location choice of foreign affiliates is not homogenous across sectors either. Domestic skills and economic stability appear to be clearly significant for the location of services investments but not for manufacturing activities. These results are consistent with the idea that investors in each sector have different motivations for locating foreign

\footnotetext{
${ }^{5}$ And particularly, in Latin America, Africa, Asia, and Central and Eastern Europe.

${ }^{6}$ This is the case of Spies (2010), who examined the location determinants of manufacturing and services FDI in Germany.
} 
affiliates in transition and developing countries. Thirdly, the outcomes obtained indicate a negative influence of higher labour costs and institutional uncertainty on the attraction of FDI, while the availability of infrastructures and distance will have a positive effect. Finally, the estimates of the nested and mixed models show that substitution patterns among alternative locations exist, depending on the country risk level for multinational services firms.

The rest of the paper is organised as follows. In the next section, we provide some stylised facts and a descriptive overview of Spanish FDI flows during recent decades. Section 2 presents a brief review of both the theoretical and the empirical literature on the subject, leading to testable hypothesis relating to the location pattern of Spanish MNEs. Section 3 describes the methodology employed. In this section, we present the specification of the model, the scope and data, and the estimation techniques used in the econometric analysis. Section 4 shows the estimation results and the final section concludes.

\section{Stylised facts: the Spanish experience}

The progress of Spanish FDI during the last 30 years has been irrefutably outstanding. According to UNCTAD figures, Spain's cumulative investment abroad represented barely $3 \%$ of its GDP in the early 80 s. At the beginning of the $90 \mathrm{~s}$, the rate of Spain's cumulative investment abroad with respect to GDP rose to 12.75 , but by 2010 the outward FDI stock already represented more than $45 \%$ of the GDP. Companies, such as Banco de Santander and BBVA (both companies among the 25 largest financial institutions in the world), Telefónica (the world's $11^{\text {th }}$ largest telecommunications provider), Repsol-YPF, the ninth largest oil company and Inditex (the owner of the Zara brand), one of the leading apparel designers, have catapulted Spain as one of the world's ten largest foreign investors (Guillén 2005). In 2013, the Spanish FDI outward stock represented the 47.3 per cent of the GDP (UNCTAD 2014).

The last few decades have also been marked by a process of internationalisation of Spanish firms in developing and transition economies. Quantitatively speaking, around $40 \%$ of total Spanish outward FDI was located in developing and transition economies, Latin American and European countries being the main recipients of the investments of Spanish MNEs. As a consequence of the narrow historical and cultural linkages, on the one hand, and the liberalisation process that many Latin American countries began in the 90 s, on the other hand, the Spanish firms initiated during those years an international expansion through new investments within this area. A second wave of foreign investments by Spanish firms took place later on, at the beginning of the new millennium, in the Central and Eastern European Countries, coinciding with the modernisation and the political approach of these economies towards the European Union. Indeed, by 2010, the two areas, Latin America and the CEE, accounted for more than 90\% of the Spanish FDI flows in transition and developing economies (International Trade Center 2011).

Another remarkable feature of the Spanish multinational firms that invest in developing and transition economies is the relevance of foreign investments in the services sector. Particularly, in 2010 the share of Spanish foreign affiliates in services represented 
about two-thirds of total Spanish investments in developing and transition economies. Most of these affiliates are located in Latin American countries and, to a lesser extent, in CEE countries ${ }^{7}$.

\section{Underlying literature and hypothesis development}

The choice of location is at the core of the decisions that multinational firms need to make in their process of internationalisation (Flores, Aguilera 2007). A recent survey conducted by the UNCTAD on managers from 2.272 MNEs (among the largest in the world) shows that the characteristics of the local market and the accessibility to other surrounding markets explain the largest proportion of the responses by MNEs when choosing the destination of investment abroad (UNCTAD 2009: 44). This is followed by the presence of suppliers, partners, and competitors (agglomeration externalities), labour market conditions, macroeconomic stability, quality of infrastructures, access to natural resources and, to a lesser extent, access to capital markets or the availability of specific incentives.

These perceptions are largely consistent with the factors that empirical academic research has highlighted as the most important in explaining the location decision of MNEs and the direction of FDI flows. However, much of the theoretical foundation of the location decisions of MNEs is still quite fragmented, traditionally coming from different fields of international business, industrial organisation or international economics, and more recently from "new" economic geography 8 .

In this literature, the motives driving firms to engage in foreign investment and the nature of firms are interrelated ${ }^{9}$. The motives are classified in four groups: strategic assetseeking, resource-seeking, market-seeking or efficiency-seeking, while this literature has traditionally distinguished between horizontally and vertically integrated MNEs.

Thus, the location decision of market-seeking investment made by horizontal MNEs relies on the trade-off between maximising proximity to customers and concentrating production to achieve scale economies. The size and quality of the host market emerges as one of the main determinants of the location decisions of MNEs ${ }^{10}$. Recently, Head and Mayer (2004) have enriched the notion of market access by introducing the impor-

\footnotetext{
${ }^{7}$ Additionally, unlike the industrial sector with a great sectoral dispersion of affiliates, in the services sector, the Spanish FDI is concentrated on a few activities. Indeed, finance, business activities, and wholesale and retail trade account for over $56 \%$ of total Spanish FDI in services over the analyzed period.

${ }^{8}$ Probably one of the few exceptions in the traditional literature comes from Dunning $(1998,2001)$ and his eclectic paradigm, which provides a unified framework for the analysis of MNEs' location decisions. An interesting discussion on the different approaches adopted by economic geographers, international economists, and international business and management specialists on the issue of the investment location behaviour of MNEs can be seen in McCann (2011).

${ }^{9}$ This interrelation is particularly evident in the internalisation approach (Buckley, Casson 1976) and it is present across all the research of what has become known as the "Reading School" of international business (see Rugman 2010).

${ }^{10}$ Accordingly, most works support a positive association between the market size of the host economy and foreign investment inflows (Bevan et al. 2004; Kang, Jiang 2012).
} 
tance of market potential in multinationals' location choice. This concept, coming from the economic geography literature, extends the role played by the host market size to the size and accessibility of surrounding markets ${ }^{11}$. Therefore, our first hypothesis is that the probability of choosing a certain location increases with the market potential of this particular location.

Also from recent developments in economic, agglomeration economies have become commonplace in the literature on the determinants of location decisions of MNEs and FDI $^{12}$. As Disdier and Mayer (2004) mentioned, the existence of a wide range of knowledge productivity spillovers generated by agglomeration provides incentives for firms to concentrate in areas with numerous other producers. Moreover, in the case of service affiliates, or when investments are of the market-seeking type taken by horizontally integrated firms in manufacturing industries, the increased need for interaction with the local environment and the increasingly decentralised organisational structure of MNEs tends to reinforce the positive effect of agglomeration economies (see Nachum 2000) ${ }^{13}$. Finally, the agglomeration economies may further rest on the nationality of the competitors, as stated by Crozet et al. (2004). Thus our second hypothesis is that the probability of choosing a certain location will be positively correlated with the relative level of agglomeration economies. Yet, there may be differences in the magnitude of the effects depending on the nationality of the firms operating in each market.

Proximity to the home country is also found to be a relevant determinant in the location choice of MNEs, although the impact of this variable on foreign investments is far from being unambiguous. Depending on the horizontal or vertical orientation of MNEs, distance, as a proxy of transport cost, is expected to have a positive or negative influence on FDI, respectively. But, this variable, as pointed out by Disdier and Mayer (2004), may also be capturing transaction costs associated with the existence of information asymmetries, cultural differences, and unfamiliarity with the legal framework. In sum, our hypothesis about distance is that it can be either positively or negatively correlated with the probability of location, depending on the type of firms and investment purposes. If horizontally integrated (market-seeking) MNEs are dominant, the expected sign on distance will be positive, while if vertically integrated (efficiency-seeking) firms dominate, the expected sign will be negative.

As pointed out by Dunning, "much of the FDI in developing countries is prompted either by traditional market-seeking motives, or by the desire to take advantage of lower

\footnotetext{
${ }^{11}$ Other authors that show the relevance of market potential in the location decision of foreign firms include Basile et al. (2008), Crozet et al. (2004), Pusterla and Resmini (2007), among others.

${ }^{12}$ See Nachum (2000) for a review of the explanatory power of theoretical and empirical concepts drawn from economic geography for the location of MNEs. Evidence on agglomeration economies is found, for example, in the works of Head and Mayer (2004) for US and Japanese firms investing in Europe, respectively; Disdier and Mayer (2004) for French firms locating in Western and Eastern Europe; Mataloni (2011) for US multinational firms investing in the Asia-Pacific area; Pusterla and Resmini (2007) for the CEE region.

${ }^{13}$ Although the increased competition associated with agglomeration may deter the entry of new firms (Crozet et al. 2004), empirical evidence on MNEs support the dominance of agglomeration forces over dispersion ones (Disdier, Mayer 2004: 283).
} 
(real) labour costs" (Dunning 1998: 54). Thus, the availability and cost of labour becomes a location advantage for both horizontally and vertically integrated MNEs. This advantage seems to be especially relevant, however, for vertically integrated MNEs, which fragment the production process into stages, seeking improvements in productive efficiency (efficiency-seeking investment) or the availability of certain resources or strategic assets. In this case, the probability of taking the decision to invest abroad increases with the possibility of avoiding supply constraints or obtaining cost advantages in production. Accordingly, in this work, we check whether high labour costs reduce the probability of MNEs locating their affiliates in that country.

But, in addition to the cost of labour, many works have emphasised the relevance of skilled labour as a determinant of foreign investment flows, especially into developing and transition countries (see, for instance, Noorbakhsh et al. 2001). For many authors, human capital development is possibly more important in service FDI than in manufacturing FDI. The non-tradable nature of services makes domestic skills particularly relevant, as service MNEs are frequently forced to reproduce home country technologies in their foreign affiliates (Blomström, Kokko 2002). Therefore, we expect that a higher availability of skilled labour in a country will attract more foreign firms, this effect being stronger in the service sector than in the manufacturing sector.

Also the availability and quality of infrastructures affect both the capacity of developing countries to attract FDI and their ability to benefit from inward FDI flows (see, for instance, Campos and Kinoshita 2006, Gorbunova et al. 2012, or Alguacil et al. 2011). For Graf and Mudambi (2005), the importance of infrastructures depends also on the specific requirements of the industry. In this respect, the availability of a telecommunications infrastructure may be considered an important determinant in the location decision of service FDI, while road density is probably more relevant for manufacturing FDI. Therefore, our hypothesis states that an extensive infrastructure endowment increases the success of a country when it comes to attracting MNEs'subsidiaries. But the attractiveness of a specific type of infrastructure may differ for industrial or for service companies.

Recent empirical works have further identified macroeconomic and institutional instability and financial risk as discouraging factors for FDI, especially for developing and transition economies ${ }^{14}$. This literature highlighted that MNEs will prefer to invest in countries with higher stability at the macro level, as the economic security and business opportunities increase. Similarly, less corruption and an efficient institutional system that lead to reduced investment-related transaction costs may help to attract FDI (see Coeurderoy and Murray 2008, Godinez and Liu 2015). Therefore, we expect that the better the macroeconomic stability and institutional framework in a country the more likely is to be selected as a destination for MNEs' subsidiaries. Some studies have also shown the importance of country-risk for international business. Forssbaeck and

\footnotetext{
${ }^{14}$ See the special issue of the International Business Review on Institutions and International Business, published in 2002; or more recently Campos, Kinoshita (2006), Peng et al. (2008), Cantwell et al. (2010), Castiglione et al. (2012), Gorbunova et al. (2012), Tintin (2013) or Sánchez-Martín et al. (2014).
} 
Oxelheim (2008), for instance, found strong evidence of the importance of financial factors in explaining cross-border investments. This leads service MNEs to prefer lowrisk economies as host countries in which to locate their subsidiaries. Thus, our last hypothesis states a negative influence of a higher economic and financial risk environment on the location of foreign affiliates, which is especially important in the case of service activities.

\section{Methodology}

\subsection{Model specification}

In this section, we empirically analyse the location choice of a Spanish multinational firm that is faced with a large number of potential destinations in which to locate its affiliates, taking into consideration the specific characteristics of the alternative locations. To do so, we estimate a set of logit models, where the dependent variable that represents the binary response of firms' location decision takes the value of one $\left(Y_{i j}=1\right)$ when the multinational firm chooses country $j$ as the location for affiliate $i$ and zero for other alternative locations $\left(Y_{i j}=0\right)$.

In accordance with our previous discussion, we consider the following model:

$$
Y_{i j}(0,1)=\alpha+\sum \beta_{a} X_{i j}^{a}+\sum \beta_{b} X_{i j}^{b}+\varepsilon_{i j},
$$

where, on the one hand, we include the most commonly used determinants of FDI related to the size and quality of the host market (market potential and income per capita), geographical proximity and agglomeration forces $\left(X_{i j}{ }^{a}\right)$ as explanatory variables. On the other hand, we add a set of specific factors which are crucial for understanding the location decision of FDI within countries undergoing economic development and transition, such as skilled workforce, quality of infrastructures, macroeconomic and institutional stability, and financial risk $\left(X_{i j}^{b}\right)$.

\subsection{Scope, variables and data}

In contrast to other papers that focus on a restricted sample, we analyse all foreign investments undertaken by Spanish firms in transition and developing economies between 1990 and 2010. Specifically, our empirical analysis is based on a dataset that comprises 4,177 foreign affiliates of 826 Spanish parent companies that located in 52 developing and transition countries between 1990 and $2010^{15}$. As explanatory variables, we include those specific characteristics of the different destinations that may encourage or deter foreign investments in developing and transition economies, such as previously men-

\footnotetext{
${ }^{15}$ In concrete, the sample comprises 38 developing countries (Angola, Antigua and Barbuda, Algeria, Argentina, Bahamas, Bahrain, Bolivia, Brazil, Cape Verde, Chile, Colombia, Costa Rica, Dominican Republic, Ecuador, Egypt, El Salvador, Guatemala, Honduras, Indonesina, India, Iran, Mexico, Moldavia, Morocco, Mozambique, Nicaragua, Panama, Paraguay, Peru, Singapore, South Africa, South Korea, Thailand, Taiwan, Tunisia, Turkey, Uruguay and Venezuela) and 14 transition economies (Bulgaria, Czech Republic, China, Croatia, Cyprus, Hungary, Latvia, Malta, Poland, Romania, Russian Fed., Serbia and Montenegro, Slovakia and Ukraine). The data was compiled from the Investment Map database (International Trade Center 2011).
} 
tioned (for their definition and source see Table A.1 in the Appendix) ${ }^{16}$.

In particular, the effect of the market size on FDI location is captured here by the market potential index. This index reflects both the size of the host market and its attractiveness as a means to access other nearby important location markets ${ }^{17}$. In some empirical works, the market demand and the quality of the target market are proxied by the income per capita (see, for instance, Kang and Jiang 2012). This factor seems to be especially important from the perspective of the location of services activities, given the higher income elasticity of these activities. However, per capita income might also be capturing the negative influence of higher labour costs on investments, especially if a specific labour cost variable is not included in the analysis, as is our case. The difficulty of having a homogeneous wage cost series for the entire sample, as well as its high correlation with GDP per capita, has prevented it from being included in our analysis. On the other hand, high labour costs might be a signal of highly skilled workers, which in turn may attract the location of higher value-added foreign activities. To disentangle the two effects, in this work we have included the non-income Human Development Index (HDI) published by United Nations Development Programme (2011) as a measure of the availability of skilled labour ${ }^{18}$.

Concerning the role played by agglomeration economies in the attraction of FDI, we follow Pusterla and Resmini (2007) and employ Hoover's location index as a relative measure of agglomeration ${ }^{19}$. Particularly, in order to capture the different impacts of the concentration of Spanish-owned and other foreign-owned firms on the attraction of FDI, we computed these indexes separately for Spanish and non-Spanish affiliates. ${ }^{20} \mathrm{In}$

${ }^{16}$ The descriptive statistics and the correlation tests of the variables included in the model are available on request.

${ }^{17}$ Similar to the works of Crozet et al. (2004) and Spies (2010), this variable is calculated here as:

$$
M K P_{j}=G D P_{j}+\sum_{j \neq k}\left(\frac{G D P_{k}}{\text { dist }_{j k}}\right),
$$

where country $j$ is the host country and country $k$ is a neighbouring country (that is, a country that shares a common border with the host country), whose influence depends on distance (dist). Own elaboration (the GDP is obtained from World Development Indicators database, World Bank 2012).

${ }^{18}$ The non-income HDI is a composite index that combines indicators of educational attainment and life expectancy, and hence a greater value of this index is associated with a higher value of human development.

${ }^{19}$ According to these authors, the absolute measure of the total number of foreign affiliates might not be controlling for other relevant effects related with agglomeration patterns.

${ }^{20}$ In particular, they are defined as:

$$
H_{h}^{j}(w)=\frac{N_{h}^{j}(w) / \sum_{j} N_{h}^{j}(w)}{\sum_{h} N_{h}^{j}(w) / \sum_{h} \sum_{j} N_{h}^{j}(w)},
$$

where $N_{h}^{j}(w)$ is the total number of foreign affiliates in sector $h$ and country $j$, and $w$ is equal to $s$ for Spanish-owned firms and $f$ for foreign-owned firms. Accordingly, $H_{i}^{j}(s)$ and $H_{i}^{j}(f)$ are greater than one when a country $j$ has a concentration of Spanish- or foreign-owned affiliates, respectively, in sector $h$ that is higher than other countries, while these indexes are equal to zero when foreign affiliates in sector $h$ are completely dispersed across countries. 
addition, we add the geographical distance between (the capital cities of) the home and host countries as a proxy of both transport costs and transaction costs that arise from cultural differences and unfamiliarity with the legal framework.

To account for the availability and quality of infrastructures, two variables were inserted in our model, given the different infrastructure requirements for services and manufacturing FDI. In the case of services FDI, the total numbers of internet users was considered a proxy of infrastructures, while for FDI in manufactures, road density was introduced instead. Furthermore, we include the inflation rate and the control of corruption index from the governance indicators proposed by Kaufmann et al. (2010) to measure the impact that macroeconomic instability and the quality of institutions, respectively, have on the location choice of FDI. Finally, in order to control for the influence of the domestic financial environment and the overall political climate on the entry of FDI, a country-risk variable was also used in some empirical stages. In particular, the role that a risky economic and financial environment may play in attracting FDI has been captured here by the Standard and Poor's index. Higher values of this index are associated with less risky countries, and hence with higher investment projects.

\subsection{Estimation techniques}

As mentioned earlier, we employ logit models to estimate the determinants of the location choice of foreign subsidiaries by matrix companies. Based on the Random Utility Maximisation framework, these models assume that each investor $i$ that faces a finite set of mutually exclusive locations selects the country $j$ that yields the highest profit (i.e., $\pi_{i j}>\pi_{i l} \forall l \neq j$ and $\left.l=1, \ldots, L\right)$. The expected profit of firm $i$ from each location $j$ consists of two components, the deterministic part, which depends on the observed attributes of each location choice $j, X_{i j}$, and the unobservable part, which is captured by a stochastic term, $\varepsilon_{i j}$ (thus, $\pi_{i j}=\beta_{h}{ }^{\prime} X_{i j}+\varepsilon_{i j}$, where $\left.h=m, s\right)^{21}$. Given that $\varepsilon_{i j}$ is unknown, the final choice is predicted in terms of probability. More specifically, the probability of firm $i$ choosing location $j$ can be described as: $P_{i j}=P\left(\pi_{i j}>\pi_{i l}\right), \forall l \neq j \quad(l=1, \cdots, L)$.

To solve the above equation, the traditional conditional logit (CL) model assumes that the error term is independently and identically distributed (iid), with type I extreme value distribution (McFadden 1973) ${ }^{22}$. Accordingly, the ratio of probabilities of investing in two locations depends only on the attributes of these two locations, and is independent of the attributes of other alternatives. This assumption (known as the independence of irrelevant alternatives, IIA, property), however, does not hold when different groups of countries have similar unobservable characteristics, so that the errors would be positively correlated across choices. Even if researchers do not observe these characteristics, investors might not contemplate all locations as equal substitutes. In this case, the CL estimates would be biased, even when country-specific effects are considered.

${ }^{21}$ In this work, we assume that in the location choice there may be different sensitivities to the different determinants according to the type of investor, i.e., manufacturing MNEs $(m)$ or service MNEs $(s)$.

${ }^{22} \mathrm{McF}$ adden (1973) proposed modelling the expected utilities in terms of characteristics of the alternatives rather than attributes of the individuals. 
The restrictive IIA assumption is partially relaxed in the nested logit (NL) model. This model allows some correlation between errors among choices within the same mutually exclusive group (or nest), but it maintains the hypothesis of no correlation among alternatives across nests ${ }^{23}$. Thus, through the estimation of a NL model, we seek to obtain unbiased parameters and to find the nesting structure supported by the data, thus enabling us to identify which groups of countries are perceived as closer substitutes by Spanish MNEs.

In particular, the NL model assumes that the profits for investor $i$ in location $j$ in nest $k$ depend on both a set of characteristics that are specific to location $j, X$, and some attributes describing nest $k, W$ (that is, $\pi_{i j}=\beta_{h}{ }^{\prime} X_{i j}+\delta_{h}{ }^{\prime} W_{i k}+\varepsilon_{i j}$ ). The degree of independence in unobserved utility among the alternatives in nest $k$ is measured by the parameter of the inconclusive value (IV), $\lambda_{k}$, which can be interpreted as the degree of dissimilarity between the alternatives within a nest (Train 2003) ${ }^{24}$. If all the $\lambda$ parameters are between 0 and 1, alternatives within the same nest are perceived by firms as closer substitutes to one another.

When the number of alternatives is large (as in this case), and thus the possible number of nesting structures increases, finding the appropriate nesting structure may be a difficult task. Therefore, as a more flexible way to capture any correlation pattern between alternatives, in a final stage, we estimate a mixed logit (MXL) model. This methodology will make it possible both to recognise any correlation of random parameters of attributes that are common across alternatives, and to check the robustness of our previous results (as this is a more efficient estimation method).

In the MXL model, the error term is composed of two terms: $u_{i j}$, which is assumed to be iid (with type I extreme value distribution), and $\alpha_{i}^{\prime} Y_{i j}$, which induces heteroskedasticity and correlation across alternatives (thus relaxing the IIA assumption). Accordingly, the profit from location $j$ can be denoted as $\pi_{i j}=\beta_{h}^{\prime} X_{i j}+\alpha_{i, h}^{\prime} Y_{i j}+u_{i j}$, where $Y_{i j}$ is a vector of observed variables of each location choice and $\alpha$ is a vector of randomly distributed parameters. In this model, the variances of the error components capture the magnitude of the correlations across alternatives.

The greater flexibility of MXL models allowing for more complex substitution patterns among alternatives makes this methodology particularly attractive for the study of the location decisions of $\mathrm{MNEs}^{25}$. However, although this method can be used to endog-

${ }^{23}$ The idea behind the nested model is that the comparable alternatives are grouped, such that the structure choice is set as a tree: foreign investors choose between nests on an upper level and between countries within a nest on a lower level. But this does not necessarily entail a sequential decision.

${ }^{24}$ If $\lambda_{k}=1$, the alternatives are completely independent and the NL collapses to the CL model presented above. In contrast, if $\lambda_{k}=0$, the nest is the relevant decision in the location choice, and the alternatives inside nest $k$ are perfect substitutes.

${ }^{25}$ Indeed, with an MXL model it is possible to obtain any substitution pattern among alternatives by making the appropriate choice of the variables that enter in the error components, $Y_{i j}$. In the CL model, however, this last term is identically equal to zero, thus implying no correlation in profits across alternatives. In the NL model, $Y_{i j}$ is defined as a vector of dummy variables, $d_{j k}$, which are equal to one when the alternative $j$ is in nest $k$ and zero otherwise. 
enously determine those common elements that make different locations more competitive with each other, it does not allow us to identify which countries can be grouped in terms of greater similarity in the competition for the attraction of foreign investors, as occurs with the nested model.

\section{Estimation results}

As a benchmark, we begin our empirical analysis with the standard conditional (fixed effect) logit model. In Table 1, the results of this estimation are reported both for the whole sample (Columns 1 to 3 ) and for two sectoral subsamples: manufacturing (Columns 4 and 5) and services firms (Columns 6 and 7). In the baseline model (Columns 1, 4 and 6), the probability of an MNE locating in one particular country depends on the traditional determinants of FDI (market potential, per capita income, distance, and the agglomeration effects). In the augmented models (Columns 2, 3, 5 and 7), the role of other local conditions, such as the macroeconomic instability, the institutional framework, the quality of infrastructures ${ }^{26}$ and human capital are also taken into consideration.

Similar to previous empirical studies, and in line with our expectations, the outcomes clearly indicate that market potential is a key determinant of the MNEs' location choice. The coefficient on this variable is positive and strongly significant in all regressions. This result indicates that the probability of a Spanish MNE choosing a location increases with both the host country market size and a greater access to other potential markets closed to them. The estimates further reveal that distance, when significant, is positively related to the location patterns of Spanish MNEs. This finding seems to agree more with the market-seeking FDI hypothesis than with the efficiency-seeking FDI hypothesis 27.

Location choice also seems to be positively influenced by the level of income, as shown by the coefficient on per capita GDP for the whole sample, suggesting that the potential negative effects of higher labour costs are more than offset by the positive impact of a greater level of development or purchasing power in the home country. However, the division of the sample between manufactures and services shows an interesting result, namely, a negative impact of the per capita GDP on attracting a foreign investor in the manufacturing sector. For services FDI, however, the harmful effect of this variable only becomes clear when the human development variable is added. This is not surprising if we consider that in the more parsimonious model, per capita income might be capturing both the positive influence of human capital and the negative impact of higher labour costs. Indeed, while non-income HDI have a positive and significant influence on the location of services FDI, which supports our hypothesis and the results obtained in previous empirical works (Blomström, Kokko 2002), the effect of this variable in the manufacturing sector is insignificant.

\footnotetext{
${ }^{26}$ We initially estimated the model with both variables (internet users and road density) together in the regressions. The estimates revealed the differential impact of each of these variables in the different sectors. Results are available upon request.

${ }^{27}$ In the case of Spain, distance could also be capturing cultural similarities (faraway countries, such as those in Latin America, are more familiar with Spanish traditions than others that are closer).
} 
Table 1. Regression results from conditional logit models

\begin{tabular}{|c|c|c|c|c|c|c|c|}
\hline & \multicolumn{3}{|c|}{ TOTAL } & \multicolumn{2}{|c|}{ MANUFACTURING } & \multicolumn{2}{|c|}{ SERVICE } \\
\hline & (1) & (2) & (3) & (4) & (5) & (6) & (7) \\
\hline $\begin{array}{l}\text { Market } \\
\text { potential }\end{array}$ & $\begin{array}{c}1.039^{* * *} \\
(0.019)\end{array}$ & $\begin{array}{c}1.018^{* * *} \\
(0.019)\end{array}$ & $\begin{array}{c}1.016^{* * *} \\
(0.022)\end{array}$ & $\begin{array}{c}1.202^{* * *} \\
(0.044)\end{array}$ & $\begin{array}{c}1.255^{* * *} \\
(0.098)\end{array}$ & $\begin{array}{c}1.358^{* * *} \\
(0.039)\end{array}$ & $\begin{array}{c}1.259^{* * *} \\
(0.035)\end{array}$ \\
\hline $\begin{array}{l}\text { GDP per } \\
\text { capita }\end{array}$ & $\begin{array}{c}0.373^{* * *} \\
(0.037)\end{array}$ & $\begin{array}{c}0.191^{* * *} \\
(0.055)\end{array}$ & $\begin{array}{c}0.087 \\
(0.061)\end{array}$ & $\begin{array}{l}-0.006 \\
(0.080)\end{array}$ & $\begin{array}{c}-0.491^{*} \\
(0.256)\end{array}$ & $\begin{array}{c}0.275^{* * *} \\
(0.040)\end{array}$ & $\begin{array}{c}-0.444^{* * *} \\
(0.071)\end{array}$ \\
\hline Distance & $\begin{array}{l}-0.038 \\
(0.034)\end{array}$ & $\begin{array}{l}0.086^{* *} \\
(0.038)\end{array}$ & $\begin{array}{l}0.068^{*} \\
(0.040)\end{array}$ & $\begin{array}{c}0.005 \\
(0.058)\end{array}$ & $\begin{array}{c}0.087 \\
(0.112)\end{array}$ & $\begin{array}{c}0.260^{* * *} \\
(0.053)\end{array}$ & $\begin{array}{c}0.460^{* * * *} \\
(0.053)\end{array}$ \\
\hline $\begin{array}{l}\text { H. index } \\
\text { Spain }\end{array}$ & $\begin{array}{c}1.299^{* * *} \\
(0.033)\end{array}$ & $\begin{array}{l}1.316^{* * *} \\
(0.037)\end{array}$ & $\begin{array}{c}1.266^{* * *} \\
(0.036)\end{array}$ & $\begin{array}{c}1.476^{* * *} \\
(0.071)\end{array}$ & $\begin{array}{l}1.640^{* * *} \\
(0.124)\end{array}$ & $\begin{array}{c}4.972^{* * *} \\
(0.180)\end{array}$ & $\begin{array}{c}4.040^{* * *} \\
(0.124)\end{array}$ \\
\hline $\begin{array}{l}\text { H. index } \\
\text { foreign }\end{array}$ & $\begin{array}{c}3.803^{* * *} \\
(0.598)\end{array}$ & $\begin{array}{c}2.063^{* * *} \\
(0.653)\end{array}$ & $\begin{array}{c}2.810^{* * *} \\
(0.662)\end{array}$ & $\begin{array}{c}10.446^{* * *} \\
(0.539)\end{array}$ & $\begin{array}{c}12.169^{* * *} \\
(1.014)\end{array}$ & $\begin{array}{c}2.043^{* * *} \\
(0.417)\end{array}$ & $\begin{array}{l}0.750^{* *} \\
(0.377)\end{array}$ \\
\hline Inflation rate & & $\begin{array}{c}-0.287^{\text {*** }} \\
(0.043)\end{array}$ & $\begin{array}{c}-0.421^{* * *} \\
(0.044)\end{array}$ & & $\begin{array}{l}-0.120 \\
(0.172)\end{array}$ & & $\begin{array}{c}-0.615^{* * *} \\
(0.064)\end{array}$ \\
\hline $\begin{array}{l}\text { Control of } \\
\text { corruption }\end{array}$ & & $\begin{array}{l}0.131^{\text {** }} \\
(0.055)\end{array}$ & $\begin{array}{c}0.048 \\
(0.058)\end{array}$ & & $\begin{array}{l}0.354^{*} \\
(0.201)\end{array}$ & & $\begin{array}{l}0.117^{* *} \\
(0.058)\end{array}$ \\
\hline Road density & & $\begin{array}{c}0.194^{* * *} \\
(0.021)\end{array}$ & & & $\begin{array}{c}0.212^{* * *} \\
(0.039)\end{array}$ & & \\
\hline Internet users & & & $\begin{array}{c}0.547^{* * *} \\
(0.067)\end{array}$ & & & & $\begin{array}{c}0.447^{* * *} \\
(0.087)\end{array}$ \\
\hline $\begin{array}{l}\text { Non-income } \\
\text { HDI }\end{array}$ & & $\begin{array}{l}-.0183 \\
(0.354)\end{array}$ & $\begin{array}{c}0.367 \\
(0.431)\end{array}$ & & $\begin{array}{c}1.802 \\
(1.369)\end{array}$ & & $\begin{array}{c}4.783^{* * *} \\
(0.622)\end{array}$ \\
\hline $\begin{array}{l}\text { Log- } \\
\text { likelihood }\end{array}$ & -10197.0 & -10107.5 & -10095.4 & -2378.4 & -2344.0 & -8219.1 & -8025.3 \\
\hline $\begin{array}{l}\text { Number } \\
\text { of obs. }\end{array}$ & 217204 & 217204 & 217204 & 54184 & 54184 & 163020 & 163020 \\
\hline
\end{tabular}

Note: ${ }^{* * *},{ }^{* *}$ and ${ }^{*}$ denote significance levels at the $1 \%, 5 \%$ and $10 \%$, respectively. Robust standard errors are in parentheses.

Consistent with our expectations, we also find strong evidence of a positive influence of the agglomeration forces. The coefficients on the Hoover's location index for Spanish and foreign firms are both positive and statistically significant at the $1 \%$ level in all cases. This result corroborates our hypothesis that the positive spillovers arising from agglomeration are sufficiently important to more than offset the potential adverse effects of spatial clustering on increased firm competition. Yet, the estimates from the sectoral analysis reveal a different behaviour for the agglomeration effects across sectors. For Spanish firms investing in manufactures, the spillovers arising from a higher concentration are greater in the case of non-Spanish-owned affiliates. But, when investing in services, the coefficients on the agglomeration variables are higher for the Spanish-owned affiliates, which suggest that for service investors the presence of other Spanish firms in a given country is viewed as a robust signal of the profitability of a certain loca- 
tion more than in the case of foreign-owned affiliates. Finally, our estimations confirm the importance of taking into consideration other local conditions like the role played by the macroeconomic and institutional framework and the quality of infrastructures as relevant factors in firms' location decision (as shown in Campos, Kinoshita 2006; Coeurderoy, Murray 2008; Gorbunova et al. 2012) ${ }^{28}$.

Next, with the aim of testing and partially relaxing the IIA assumption and considering the possibility of there being certain degrees of similarity among some of the alternatives, both the NL and MXL models are estimated (see Table 2). In the NL model (Columns 1 and 2), the countries have been grouped into two nests: high-risk countries and low-risk countries ${ }^{29}$. As can be seen at the bottom of Table 2, the likelihood ratio (LR) test rejects the hypothesis that the IV parameters are jointly equal to one in all cases. Consequently, the conditional and the nested logit cannot be considered equivalents. According to the IV parameters, Spanish investors in the service sector that are looking for a location for their subsidiaries perceive countries with an analogous risk index as being more similar ${ }^{30}$. However, for investments in manufactures, the values of the IV parameters are significantly larger than one, which implies that investors searching for a location for their production plants do not consider a country in a risk group more analogous to another one in the same country set, given all other determinants.

In short, we can say that in the attraction of services, FDI competition seems to be higher within locations with a similar business and financial environment, but this does not necessarily happen in the attraction of foreign manufacturing subsidiaries. Concerning the determinants of location choice, the estimated effects present similar signs as in the previous case.

Given that the risk-country tree hypothesis in the MNE location decision has been rejected for the manufacturing sector, thereby suggesting that other appropriate patterns of correlation between the error terms in the location choice may exist, a mixed logit model is subsequently estimated (Columns 3 and 4). This estimation methodology allows both an improvement in the quality of the estimation, and the identification of those factors that make countries more similar from the point of view of foreign investment.

\footnotetext{
${ }^{28}$ To account for potential regional location-specific determinants in this work, we have further estimated the model with the incorporation of regional dummy variables. The estimates (available on request) show similar results on the coefficients of the explanatory variables to those obtained previously. Concerning the regional effects, the coefficients reveal, on the one hand, that Spanish firms tend to invest more in Latin American countries than in the other regions in both sectors. On the other hand, for the services sectors, we find that Spanish MNEs seem to be sceptical about locating affiliates in Asia.

${ }^{29}$ We have also tried to take into account regional effect similarities (Latin America, Asia, CEE and Africa) with other nesting structures. However, the equal substitution hypothesis among groups was not rejected. Results are available on request.

${ }^{30}$ An adequate nesting structure also requires that the inconclusive value parameter lie within the unit interval for all the nests, thus suggesting that locations within a nest are not completely independent.
} 
Table 2. Regression results from nested and mixed logit models

\begin{tabular}{|c|c|c|c|c|}
\hline & \multicolumn{2}{|l|}{ NL } & \multicolumn{2}{|l|}{ MXL } \\
\hline & MANUFACTURING & SERVICE & MANUFACTURING & SERVICE \\
\hline & $(1)$ & (2) & (3) & (4) \\
\hline Market potential & $\begin{array}{c}1.455^{* * *} \\
(0.183)\end{array}$ & $\begin{array}{c}0.751^{* * *} \\
(0.038)\end{array}$ & $\begin{array}{c}2.071^{* * *} \\
(0.280)\end{array}$ & $\begin{array}{c}2.524^{* * *} \\
(0,079)\end{array}$ \\
\hline GDP per capita & $\begin{array}{c}-0.637^{* * *} \\
(0.220)\end{array}$ & $\begin{array}{c}-0.326^{* * *} \\
(0.039)\end{array}$ & $\begin{array}{c}-0.806^{* * *} \\
(0.241)\end{array}$ & $\begin{array}{c}-0.970^{* * *} \\
(0.080)\end{array}$ \\
\hline Distance & $\begin{array}{l}-0.021 \\
(0.107) \\
\end{array}$ & $\begin{array}{c}0.175^{\text {*** }} \\
(0.025)\end{array}$ & $\begin{array}{l}-0.156 \\
(0.099)\end{array}$ & $\begin{array}{c}0.174 \\
(0.137)\end{array}$ \\
\hline H. index Spain & $\begin{array}{c}1.792^{* * *} \\
(0.241)\end{array}$ & $\begin{array}{c}2.093^{* * *} \\
(0.122)\end{array}$ & $\begin{array}{l}1.863^{* * *} \\
(0.256)\end{array}$ & $\begin{array}{c}6.297^{* * *} \\
(0.137)\end{array}$ \\
\hline H. index foreign & $\begin{array}{c}13.373^{* * *} \\
(1.778)\end{array}$ & $\begin{array}{c}0.398^{* * *} \\
(0.100)\end{array}$ & $\begin{array}{c}16.641^{* * *} \\
(2.607)\end{array}$ & $\begin{array}{c}0.655^{* * *} \\
(0.221)\end{array}$ \\
\hline Inflation rate & $\begin{array}{l}-0.109 \\
(0.171)\end{array}$ & $\begin{array}{c}-0.441^{* * *} \\
(0.040)\end{array}$ & $\begin{array}{c}1.001 \\
(0.184)\end{array}$ & $\begin{array}{c}-0.269^{* * *} \\
(0.089)\end{array}$ \\
\hline $\begin{array}{l}\text { Control of } \\
\text { corruption }\end{array}$ & $\begin{array}{c}0.605^{* * *} \\
(0.220)\end{array}$ & $\begin{array}{c}0.377^{* * *} \\
(0.042)\end{array}$ & $\begin{array}{c}0.984^{* * *} \\
(0.297)\end{array}$ & $\begin{array}{l}1.055^{* * *} \\
(0.088)\end{array}$ \\
\hline Road density & $\begin{array}{c}0.216^{* * * *} \\
(0.050)\end{array}$ & & $\begin{array}{c}0.225^{* * *} \\
(0.042)\end{array}$ & \\
\hline Internet users & & $\begin{array}{c}0.300^{* * *} \\
(0.035)\end{array}$ & & $\begin{array}{c}0.722^{* * *} \\
(0.079)\end{array}$ \\
\hline Non-income HDI & $\begin{array}{l}2.544^{* *} \\
(1.154)\end{array}$ & $\begin{array}{l}1.774^{* * *} \\
(0.259)\end{array}$ & $\begin{array}{c}3.93 .4^{* * *} \\
(1.310)\end{array}$ & $\begin{array}{l}5.962^{* * *} \\
(0.633)\end{array}$ \\
\hline \multirow[t]{2}{*}{ Risk } & & & $\begin{array}{c}0.574 \\
(2.259)\end{array}$ & $\begin{array}{c}0.752 \\
(0.774) \\
\end{array}$ \\
\hline & \multicolumn{2}{|c|}{ IV parameters } & \multicolumn{2}{|l|}{ SD } \\
\hline Low risk & $\begin{array}{l}1.373^{* * *} \\
(0.267)\end{array}$ & $\begin{array}{c}0.555^{* * *} \\
(0.036)\end{array}$ & & \\
\hline High risk & $\begin{array}{l}1.043^{* * * *} \\
(0.114)\end{array}$ & $\begin{array}{c}0.473^{* * *} \\
(0.021)\end{array}$ & & \\
\hline Market potential & & & $\begin{array}{c}0.977^{* * *} \\
(0.235)\end{array}$ & $\begin{array}{c}1.440^{* * *} \\
(0.067)\end{array}$ \\
\hline Distance & & & $\begin{array}{c}0.009 \\
(0.066)\end{array}$ & $\begin{array}{c}0.801^{* * *} \\
(0.218)\end{array}$ \\
\hline H. index foreign & & & $\begin{array}{l}1.978 \\
(2.540)\end{array}$ & $\begin{array}{c}0.507^{* * *} \\
(0.153)\end{array}$ \\
\hline Non-income HDI & & & $\begin{array}{c}0.200 \\
(0.374)\end{array}$ & $\begin{array}{l}2.107^{* *} \\
(1.015)\end{array}$ \\
\hline Risk & & & $\begin{array}{c}2.317 \\
(2.687) \\
\end{array}$ & $\begin{array}{c}5.443^{* * *} \\
(1.283)\end{array}$ \\
\hline LR test & $13.90^{* * *}$ & $503.74^{* * *}$ & & \\
\hline Log-likelihood & -2337.0 & -7777.4 & -2320.8 & -7350.5 \\
\hline Number of obs. & 54184 & 163020 & 54184 & 163020 \\
\hline
\end{tabular}

Note: ${ }^{* * *},{ }^{* *}$ and ${ }^{*}$ denote significance levels at the $1 \%, 5 \%$ and $10 \%$, respectively. Robust standard errors are in parentheses. In each MXL regression the standard deviation includes all the 11 variables also used as location determinants. However, in order to save space, we do not report standard deviations that are not significant in any of the subsamples used. Standard deviations for all the variables are available from the authors upon request. 
The standard deviations of the new error terms in the MXL models suggest that if a country becomes less attractive (due to changes in any of its characteristics), MNEs investing in the services sector seem more likely to locate in countries sharing similar market potential, distance, foreign firms agglomeration, availability of skilled labour force, and risk level. ${ }^{31}$ The MXL estimations also reveal that in manufacturing, MNEs tend to show a higher degree of substitution between countries with similar market potential. These results would corroborate the hypothesis of MNEs having different location decision patterns across sectors, thus suggesting that an aggregate study of this matter may provide inaccurate results.

\section{Conclusions}

The main objective of this research has been to investigate how different host country characteristics affect the location decision of MNEs in developing and transition economies. In this analysis, particular attention has been paid to the sectoral nature of firms, and more specifically to whether the different location determinants of multinational firms change when looking at manufacturing or services firms. The motives that lead them to invest abroad and the different nature of FDI to a large extent define the relevance of local factors that make recipient countries more attractive for transnational investments.

The econometric analysis was performed using a set of logit models, which enables us to test for the existence of different substitution patterns, ranging from the simpler but rigid ones displayed by the nested model to the more flexible but complex substitution pattern exhibited by the mixed one. Overall, our results show that in the case of Spain, FDI present similar patterns to those found for other developed economies: an increasing importance of the market-seeking FDI (to the detriment of the more traditional resource-seeking FDI).

In general, the estimates confirm the relevance of the variables identified by the economic and business literature that justify a horizontal expansion of firms. Distance from home country, market potential, as well as, agglomeration spillovers have a positive influence on location choice of Spanish firms in foreign markets. These findings allow us to characterise Spanish MNEs mainly as horizontal and market-seeking. Despite this, the sectoral analysis also reveals, according with the efficiency-seeking FDI determinants, a negative influence of higher labour costs in attracting Spanish MNEs.

Moreover, in agreement with our expectations, we find that the probability of an MNE from a developed country locating in a developing and transition country increases with the endowment of infrastructures and skilled labour, and the quality of institutions, while it decreases with macroeconomic and financial uncertainty. Therefore, we can conclude that, as suggested by the literature, to encourage FDI in this countries,

${ }^{31}$ In the nested model, it has already been confirmed that investors contemplate countries with a similar financial risk as closer substitutes. But with the estimation of the MXL model, we go a little further by showing that this is not the only aspect that affects substitution, but rather there is a combination of different attributes. 
the application of incentives for foreign investors are insufficient. Policies should be primarily designed to improve the overall business and financial climate through reinforcing macroeconomic and institutional stability and the infrastructure and human capital endowments.

This is particularly true in the case of services FDI. The disaggregated study shows a greater sensitivity of service MNEs to the availability of skilled labour and to the economic climate when deciding where to locate their affiliates. This would be consistent with the different nature of the service FDI (frequently information-intensive, as in the case of business and finance), as well as with the greater interaction with customers of these activities. The findings also provide empirical support to the view that services MNEs investing in developing and transition countries are risk averse in their location choice.

Finally, our exploration of the presence of possible substitution patterns among different locations has revealed the existence of significant differences between manufacturing and services FDI. In the case of manufacturing, the substitutability between destinations is determined by similar market potential. However, in the case of services, the existence of nests is considerably more complex, since they are a result of the combination of different attributes such as market potential, distance, skilled labour, and risk level.

In this work, we have however ignored how the different characteristics of multinational firms may influence their decision of locating in different foreign markets. The role of firm heterogeneity on the location choice of MNEs could be crucial for a better understanding of the differences on competitiveness of countries in providing multinational firms with location advantages. As empirical studies in this field are scarce, this could be an interesting topic for future research.

\section{Acknowledgements}

The authors thank the anonymous referees and editor for their helpful comments. Suggestions from B. Sánchez-Robles and J. A. Máñez are also acknowledged. In addition, the authors are grateful for financial support from European Union's Seventh Framework Programme (FP7/2007-2013) - grant agreement No. FP7-SSH- 612955 (FinMaP), the Spanish Ministerio de Economía y Competitividad and FEDER (ECO2014-58975-P), the Generalitat Valenciana (PROMETEOII/2014/054), and the University Jaume I (UJIB2016-53).

\section{References}

Alguacil, M.; Cuadros, A.; Orts, V. 2011. Inward FDI and growth: the role of macroeconomic and institutional environment, Journal of Policy Modelling 33: 481-496.

https://doi.org/10.1016/j.jpolmod.2010.12.004

Basile R.; Castellani, D.; Zanfei, A. 2008. Location choices of multinational firms in Europe: the role of EU cohesion policy, Journal of International Economics 74: 328-340.

https://doi.org/10.1016/j.jinteco.2007.08.006

Bevan, A.; Estrin, S.; Meyer, K. E. 2004. Foreign investment location and institutional development in transition economies, International Business Review 13: 43-64.

https://doi.org/10.1016/j.ibusrev.2003.05.005 
Blomström, M. A.; Kokko, A. 2002. FDI and human capital: a research agenda. OECD Development Centre Working Paper 195.

Blonigen, B. A.; Wang, M. 2005. Inappropriate pooling of wealthy and poor countries in empirical FDI studies, in T. Moran, E. Graham M. Blömstrom (Eds.). Does FDI promote development? Washington D.C. Institute for International Economics, 221-243.

Buckley, P. J.; Casson, M. C. 1976. The future of multinational enterprises. London: MacMillan. https://doi.org/10.1007/978-1-349-02899-3

Campos, N. F.; Kinoshita, Y. 2006. Determinants and effects of foreign direct investment in transition economies, Chapter 10 in J. Nakagawa (Ed.). Managing development: globalization, economic restructuring and social policy (Vol. 49). Routledge.

Cantwell, J.; Dunning, J. H.; Lundan, S. M. 2010. An evolutionary approach to understanding international business activity: the co-evolution of MNEs and the institutional environment, Journal of International Business Studies 41(4): 567-586. https://doi.org/10.1057/jibs.2009.95

Castiglione, C.; Gorbunova Y.; Infante D.; Smirnova, J. 2012. FDI determinants in an idiosyncratic country. A reappraisal over the Russian regions during transition years, Communist and Post-Communist Studies 45(1-2): 1-10. https://doi.org/10.1016/j.postcomstud.2012.02.006

Centre d'Etudes Prospectives et d'Informations Internationales. 2012. [online], [cited 29 July 2013]. Available from Internet: http://www.cepii.fr/

Coeurderoy, R.; Murray, G. 2008. Regulatory environments and the location decision: evidence from the early foreign market entries of new-technology-based firms, Journal of International Business Studies 39(4): 670-687. https://doi.org/10.1057/palgrave.jibs.8400369

Crozet, M.; Mayer, T.; Mucchielli, J. L. 2004. How do firms agglomerate? A study of FDI in France, Regional Science and Urban Economics 34(1): 27-54.

https://doi.org/10.1016/S0166-0462(03)00010-3

Disdier, A.-C.; Mayer, T. 2004. How different is Eastern Europe? Structure and determinants of location choices by French firms in Eastern and Western Europe, Journal of Comparative Economies 32(2): 280-296. https://doi.org/10.1016/j.jce.2004.02.004

Dunning, J. H. 1998. Location and the multinational enterprise: a neglected factor?, Journal of International Business Studies 29(1): 45-66. https://doi.org/10.1057/palgrave.jibs.8490024

Dunning, J. H. 2001. The eclectic (OLI) paradigm of international production: past, present and future, International Journal of the Economics of Business 8(2): 173-190.

https://doi.org/10.1080/13571510110051441

Flores, R. G.; Aguilera, R. V. 2007. Globalization and location choice: an analysis of US multinational firms in 1980 and 2000, Journal of International Business Studies 38(1): 1-24.

https://doi.org/10.1057/palgrave.jibs. 8400307

Forssbaeck, J.; Oxelheim, L. 2008. Finance-specific factors as drivers of cross-border investment - an empirical investigation, International Business Review 17: 630-641.

https://doi.org/10.1016/j.ibusrev.2008.09.001

Godinez, J. R.; Liu, L. 2015. Corruption distance and FDI flows into Latin America, International Business Review 24(1): 33-42. https://doi.org/10.1016/j.ibusrev.2014.05.006

Gorbunova, Y.; Infante, D.; Smirnova, J. 2012. New evidences on FDI determinants. An appraisal over the transition period, Prague Economic Papers 21(2): 129-149.

https://doi.org/10.18267/j.pep.415

Graf, M.; Mudambi, S. M. 2005. The outsourcing of IT-enabled business processes: a conceptual model of the location decision, Journal of International Management 11(2): 253-268.

https://doi.org/10.1016/j.intman.2005.03.010 
Guillén, M. F. 2005. The rise of Spanish multinationals: European business in the global economy. Cambridge: Cambridge University Press.

Head, K.; Mayer, T. 2004. Market potential and the location of Japanese investment in the European Union, The Review of Economics and Statistics 86(4): 959-972.

https://doi.org/10.1162/0034653043125257

International Trade Center. 2011. Investment Map Database [online], [cited 12 June 2014]. UNCTAD and WTO. Available from Internet: http://www.investmentmap.org/

Kang, Y.; Jiang, J. 2012. FDI location choice of Chinese multinationals in East and Southeast Asia: traditional economic factors and institutional perspective, Journal of World Business 47(1): 45-53. https://doi.org/10.1016/j.jwb.2010.10.019

Kaufmann, D.; Kraay, A.; Mastruzzi, M. 2010. The worldwide governance indicators: methodology and analytical issues. World Bank Policy Research Working Paper No. 5430.

Mataloni, R. J. 2011. The structure of location choice for new U.S. manufacturing investments in Asia-Pacific, Journal of World Business 46(2): 154-165. https://doi.org/10.1016/j.jwb.2010.05.004

McCann, P. 2011. International business and economic geography: knowledge, time and transaction costs, Journal of Economic Geography 11(2): 309-317. https://doi.org/10.1093/jeg/lbq035

McFadden, D. 1973. Conditional logit analysis of qualitative choice behaviour, Chapter 4 in P. Zarembka (Ed.). Frontiers in econometrics. New York: Academic Press, 105-142.

Nachum, L. 2000. Economic geography and the location of TNCs: financial and professional service FDI to the USA, Journal of International Business Studies 31(3): 367-385.

https://doi.org/10.1057/palgrave.jibs.8490912

Noorbakhsh, F.; Paloni, A.; Youssef, A. 2001. Human capital and FDI inflows to developing countries: new empirical evidence, World Development 29(9): 1593-1610.

https://doi.org/10.1016/S0305-750X(01)00054-7

Peng, M. W.; Wang, D. Y. L.; Jiang, Y. 2008. An institution based view of international business strategy: a focus on emerging economies, Journal of International Business Studies 39(5): 920-936. https://doi.org/10.1057/palgrave.jibs.8400377

Pusterla, F.; Resmini, L. 2007. Where do foreign firms locate in transition countries? An empirical investigation, Annals of Regional Science 41(4): 835-856.

https://doi.org/10.1007/s00168-007-0144-4

Rugman, A. M. 2010. Reconciling internalization theory and the eclectic paradigm, Multinational Business Review 18(2): 1-12. https://doi.org/10.1108/1525383X201000007

Sánchez-Martín, M. E.; de Arce, R.; Escribano, G. 2014. Do changes in the rules of the game affect FDI flows in Latin America? A look at the macroeconomic, institutional and regional integration determinants of FDI, European Journal of Political Economy 34: 279-299.

https://doi.org/10.1016/j.ejpoleco.2014.02.001

Spies, J. 2010. Network and border effects: where do foreign multinationals locate in Germany?, Regional Science and Urban Economics 40(1): 20-32.

https://doi.org/10.1016/j.regsciurbeco.2009.08.003

Standard and Poor's. 2012. [online], [cited 23 May 2013]. Available from Internet: http://www. standardandpoors.com.

Tintin, C. 2013. The determinants of foreign direct investment inflows in the Central and Eastern European countries: the importance of institutions, Communist and Post-Communist Studies 46(2): 287-298. https://doi.org/10.1016/j.postcomstud.2013.03.006

Train, K. E. 2003. Discrete choice methods with simulation. Cambridge: Cambridge University Press. https://doi.org/10.1017/CBO9780511753930

UNCTAD. 2009. World Investment Prospects Survey 2009-2011. New York and Geneva: United Nations Publications. 
UNCTAD. 2012. World Investment Report 2011: Towards a New Generation of Investment Policies. New York and Geneva: United Nations Publications.

UNCTAD. 2014. World Investment Report 2014: Investing in the SDGs: an Action Plan. New York and Geneva: United Nations Publications.

United Nations Development Programme. 2011. Human Development Report, Sustainability and Equity: A Better Future for All [online], [cited 12 June 2014]. New York: United Nations Publications. Available from Internet: http://hdr.undp.org/en/statistics/hdi/

World Bank. 2012. World Development Indicators database [online], [cited 12 June 2014]. Available from Internet: http://data.worldbank.org/data-catalog/world-development-indicators

\section{APPENDIX}

Table A.1. Summary and sources of the explanatory variables.

\begin{tabular}{|c|c|c|}
\hline Variable & Definition & Source \\
\hline Market potential & $\begin{array}{l}\text { GDP of the host country } j \text { increased } \\
\text { by the value added of all surrounding } \\
\text { countries weighted by the Euclidean } \\
\text { distance between host and surrounding } \\
\text { countries major cities. }\end{array}$ & $\begin{array}{l}\text { Own elaboration. The GDP is } \\
\text { obtained from World Development } \\
\text { Indicators (WDI) database (World } \\
\text { Bank 2012). }\end{array}$ \\
\hline GDP per capita & GDP per capita in the host country $j$. & WDI database (World Bank 2012). \\
\hline Distance & $\begin{array}{l}\text { Bilateral distance between the main } \\
\text { in home and host countries }(\mathrm{km}) \text {. }\end{array}$ & $\begin{array}{l}\text { Centre d'Etudes Prospectives et } \\
\text { d'Informations Internationales (2012). }\end{array}$ \\
\hline $\begin{array}{l}\text { Spanish } \\
\text { agglomeration }\end{array}$ & $\begin{array}{l}\text { Hoover's location index for Spanish } \\
\text { firms in the host country } j \text { over the } \\
\text { period } 1990-2010 \text {. }\end{array}$ & $\begin{array}{l}\text { Own elaboration based on Investment } \\
\text { Map database (International Trade } \\
\text { Center 2011). }\end{array}$ \\
\hline $\begin{array}{l}\text { Foreign } \\
\text { agglomeration }\end{array}$ & $\begin{array}{l}\text { Hoover's location index for foreign } \\
\text { firms in the host country } j \text { over the } \\
\text { period } 1990-2010 \text {. }\end{array}$ & $\begin{array}{l}\text { Own elaboration based on Investment } \\
\text { Map database (International Trade } \\
\text { Center 2011). }\end{array}$ \\
\hline Inflation rate & Inflation rate in the host country $j$. & WDI database (World Bank 2012). \\
\hline $\begin{array}{l}\text { Control of } \\
\text { corruption }\end{array}$ & $\begin{array}{l}\text { Level of corruption in the host } \\
\text { country } j \text {. }\end{array}$ & $\begin{array}{l}\text { Worldwide Governance Indicators } \\
\text { database (World Bank 2012). }\end{array}$ \\
\hline Internet users & $\begin{array}{l}\text { Total number of internet users in the } \\
\text { host country } j \text { (per } 100 \text { people). }\end{array}$ & WDI database (World Bank 2012). \\
\hline Road density & $\begin{array}{l}\text { Road density (km of road per sq. km } \\
\text { of land area) in the host country } j .\end{array}$ & WDI database (World Bank 2012). \\
\hline Non-income HDI & Non-income HDI in the host country $j$. & $\begin{array}{l}\text { United Nations Development } \\
\text { Programme (2011). }\end{array}$ \\
\hline Risk index & $\begin{array}{l}1 \text { if country } j \text { has a hight risk index, } \\
0 \text { otherwise. }\end{array}$ & Standard and Poor's (2012). \\
\hline
\end{tabular}

Note: All variables, except dummy variables, are estimated in log.h 
Josep MARTI is PhD student at the University Jaume I. He has been guest researcher at KOF Institute at ETH Zurich.

Maite ALGUACIL is Associate Professor at the University Jaume I and research fellow at the Institute of International Economics. Her research has been published in journals like Journal of International Development, Journal of Development Studies, Emerging Markets Finance and Trade and Journal of Policy Modeling.

Vicente ORTS is Professor in Economics at the University Jaume I of Castellon, Spain. His research has focused on international trade and foreign direct investment, economic geography and economic development. Recent work has appeared in the Journal of Developments Studies, Journal of Economics and Management Strategy, Southern Economic Journal, Papers in Regional Science and other international journals. 